\title{
Analysing The Trade EfFects of The Eu-Sa \& SADC Trading Agreements: A Panel Data ApProach
}

\author{
André Jordaan and Patrick Kanda \\ Department of Economics, University of Pretoria
}

Accepted February 2011

\begin{abstract}
This study investigates the trade effects of the EU-SA and SADC preferential trade agreements of which South Africa is a member. Using a panel data estimation of the gravity model of bilateral trade and based on data from 1994 to 2008, the study finds the EU-SA preferential trade agreement to have a significant trade expansion effect. The study further reveals that an informative conclusion on trade effects of the SADC preferential trade agreement can only be reached once the agreement has been fully operational. The study also recommends that trade policy in South Africa should increasingly be geared towards broad-based multilateral liberalisation. In addition, South Africa should promote regional economic stability and development through supporting regional trade agreement initiatives.
\end{abstract}

Key words: trade creation, trade diversion, preferential trade agreement, panel data estimation, gravity model of bilateral trade

JEL: F14; F15

1

\section{Introduction}

Preferential Trade Agreements (PTAs) have increased in number during the last decade in both developing and developed countries (Musila, 2005:117). PTAs have been said to enhance trade by approximately 50 per cent whereas a recent report from the National Bureau of Economic Research (NBER) suggests that PTAs in fact triple the volume of trade between members in the agreement (Head, 2003:11). South Africa is currently a signatory to two significant Preferential Trade Agreements (PTAs): the European UnionSouth Africa (EU-SA) agreement signed in 1999 and the Southern African Development Community (SADC) agreement ratified in 2000.

Previous research on South Africa's international trade such as Chauvin and Gaulier (2002), Rangasamy and Brick (2007), Smet (2007) and Kalaba (2007) has focussed on analysing issues such as trade liberalisation, export performance, comparative advantage, trade with developing countries vs trade with developed countries, and the determinant of
South Africa's international trade. Some other studies such as Rangasamy and Blignaut (2005) and Cassim, Onyango and Van Seventer (2004) have investigated the openness and competitiveness of the South African economy. However, few studies (Kwentua, 2006 and Holden \& McMillan, 2006) have investigated the impacts of the EUSA and SADC preferential trade agreements to which South Africa is a prominent signatory.

Following various trade reforms in the 1990s, the South African economy has been characterised by an improvement in international trade (Rangasamy \& Blignaut, 2005:375). Previous research also indicates that the EU and the USA are some of the most important destinations of South African exports in contrast with the SADC which, compared to the other groupings, is a relatively smaller trading partner (Smet, 2007:14). On the other hand, evidence based on data suggests that during the period from 1994 to 2008, there has been a significant decline and in some instances stagnation in trade between South Africa and some of its major trading partners in the EU, despite the fact that from 2000 South Africa and the EU have been part 
of the same preferential trade agreement. However, trade with countries such as China and Japan, with whom South Africa does not have a trade agreement, soared during the same period of time. Kwentua (2006) finds evidence of trade creation in the EU-SA agreement and increased trade between EU-SA members and the rest of the world. Holden and McMillan (2006) also suggest that the EU-SA agreement enhanced both exports and imports while the SADC agreement only stimulated exports for its members.

In the light of empirical evidence of reduced trade between South Africa and some of its major trading partners in the EU, as well as increased trade between South Africa and countries that are non-members of the EU-SA or SADC agreements, the purpose of this study is to investigate trade effects of preferential trade agreements in which South Africa is a member, namely the EU-SA and the SADC agreements. This study uses an augmented version of the gravity model of bilateral trade specified in Ghosh and Yamarik (2004) and a panel data estimation of the gravity model of bilateral trade as outlined in Martinez-Zarzoso and Nowak-Lehmann (2003) and Egger (2000).

The rest of the paper is organised as follows: after a review of South Africa's international trade environment and related literature in Section 2, the methodology based on the gravity model of bilateral trade framework is discussed in Section 3. Thereafter, an empirical estimation of the gravity equation is conducted in Section 4. Results are presented in Section 5 and Section 6 concludes the paper.

\section{2}

\section{Literature review}

\subsection{South Africa in global trade}

\subsubsection{Openness of the South African economy}

Rangasamy and Blignaut (2005:375-376) and Kalaba (2007:1) argue that the engagement of South Africa in the global community and the implementation of a series of new economic policies in the 1990 s caused a move from highly protected and distorted markets to open ones. Rangasamy and Blignaut (2005:375-376) also report that externally-oriented industries were found to have higher rates of growth compared to other industries in the South African economy in the post 1990 s period. The drive of this process of opening up the economy was enhanced by the endorsement in 1994 of the General Agreement on Tariffs and Trade (GATT) and the execution of PTAs with the EU and the SADC in 1999 and 2000 respectively. The salient facet of these agreements is the reduction of import protection.

The EU-SA agreement has an asymmetric nature whereby duties on 95 per cent of the EU's imports from South Africa will totally be phased out by the end of the agreement's 12-year duration; while on the other hand, only 86 per cent of South Africa's imports from the EU will become duty-free during the same period. The SADC agreement, though created in 1996, was only endorsed by 11 of its current members in 2000. According to this agreement, 98 per cent of intra SADC trade will have to become free of duty by the year 2012. Owing to the fact that South Africa is the largest economy in the region, the agreement requires it to undergo faster liberalisation reforms than other countries in the community (Mabugu \& Chitiga, 2007:5).

\subsubsection{Trade liberalisation}

South Africa's economy has experienced a steady course towards trade restructuring during the past few decades due to domestic and international pressure. The objective of this reform was to enhance the allocation of resources through more competitive and export-oriented policies. A particular emphasis was directed to the export of non-gold commodities. Consequently, some export promotion measures were adopted to counteract the anti-export bias of protection and improve the competitiveness of some industrial sub-sectors. However, these incentives to restructure trade were later on negatively affected by a significant appreciation of the rand caused by an export boom of gold commodities. Up until the late 1980s, South African exports were dominated by primary commodities, especially gold 
(Petersson, 2005:1)

According to Smet (2007:17), South Africa's trade activities expanded after it joined the WTO in 1995. Chauvin and Gaulier (2002:14) report that South Africa decreased its tariffs by approximately 4250 tariff lines between 1990 and 1996 with the aim of reducing tariff rates from around 210 to 6 in the same period. Edwards (2005:774) argues that the liberalisation of tariffs in South Africa during the 1990s caused an important decline in the level of effective and nominal protection. There was a decrease of 8.7 per cent and 35.3 per cent in the manufacturing's mean nominal and effective protection rates respectively from 1994 to 2004. All traded industries reported a decline in protection during the same period. As a consequence, fewer commodities were affected by tariff distortions in 2004 than in 1994. Nonetheless, the tariff structure still remains intricate with the tobacco, textiles, clothing and footwear industries characterised by high levels of effective and nominal protection. Edwards and Lawrence (2008:585) argue that more trade liberalisation should form part of policies aimed at improving export diversification in South Africa. They also argue that trade policy in South Africa has exercised a considerable impact on the nature and growth of trade. Before the accession of South Africa to independence, exports and imports were significantly obstructed by trade protection. Jonsson and Subramanian (2001:219) find evidence that trade liberalisation also had an important contribution to the increased longrun growth potential of South Africa through its effect on total factor productivity growth.

\subsubsection{Trade, competitiveness and growth}

According to Mtonga (2006:50-51), there was an increase in the volatility of the real exchange rate of the rand possibly due to a misaligned currency ${ }^{1}$ after the accession of South Africa to democracy in 1994. Following the appreciation of the rand, the competitiveness of South African exports on the global market eroded because South African exports became more expensive. This in turn caused a reduction in production, profits and employment. $^{2}$ This fact highlights the importance of competitiveness in international trade and its relationship with economic growth as the South African government's move to tackle the issues of high levels of unemployment and prevalent poverty has been centred on realising sustainable economic growth. Matthee and Naudé (2007:16) report that in addition to the quantity of exports, the nature and quality of commodities that are exported is very important in the analysis of export-led growth in the case of South Africa. Peet and Koch (2005:1) argue that a foundation of South Africa's economic development policy is export growth. Consequently, circumstances surrounding foreign markets also affect the performance of the South African economy.

\subsubsection{Features of South Africa's international trade}

South Africa has made important efforts aimed at supporting bilateral relations with its main trading partners. After the democratic election of 1994, the EU and the USA allowed dutyfree access for South Africa's exports to their respective markets. For instance, the African Growth and Opportunity Act (AGOA) signed in 2000 enhanced the accessibility of South Africa's exports into the US market (Petersson, 2005:1).

Aspects influencing trade development in South Africa include (Kalaba, 2007:4):

- Colonial and political history: There is a strong trade relationship between South Africa and the UK, Germany and the Netherlands;

- The nature of the commodities: Africa constitutes an important destination of exports of manufactured and finished consumer goods from South Africa whereas imports of machinery, high-tech goods and electronic equipment into South Africa originate from developed countries;

- The development of infrastructure: Major construction projects such as the Gautrain rail link, construction and upgrade of stadia, road constructions, and upgrade of highways have caused higher imports of construction machinery;

- The income level of the trading partner: South African exports have the tendency to be destined to countries with higher per 
capita GDP;

- Exchange rates: Imports into South Africa are enhanced by a strong rand to the detriment of exports. Edwards and Lawrence (2008:606) also argue that total imports and non-commodity exports were receptive to fluctuations in the real exchange rate.

Rangasamy and Brick (2007:644-645) argue that South Africa's export performance is dictated by the Organisation for Economic Cooperation and Development (OECD) growth in the long run. They also argue that South Africa's existing trading relationships should be exhaustively exploited in addition to improving the competitiveness of South African exports as well as broadening export destinations. Their study also identifies three aspects characterising trade between South Africa and its main trading partners. First, the OECD represents a significant trading partner of South Africa with 65 per cent and 59 per cent of South Africa's exports and imports respectively being accounted for by trade between South Africa and the OECD. Second, there is a huge concentration of South Africa's trading linkages, i.e. two-thirds of imports into South Africa originated from a group of twenty countries in the period from 1992 to 2005. Moreover, the very same countries absorbed approximately three quarters of exports from South Africa during that same period. Lastly, the destination of exports from South Africa became more condensed after the 1990s while on the contrary the sources of imports into South Africa were diversified.

\subsubsection{Trend analysis and composition of trade}

Table 1 shows that South Africa ranked 26th and 22nd for merchandise exports and imports respectively, not taking into consideration intra EU trade in 2008. The situation is different for commercial services trade, with South Africa ranking 28th and 23rd for exports and imports respectively, excluding intra EU trade. Therefore, it can be concluded that though South Africa has a relatively better stance in global trade than most developing countries, there still is room for improving this current stance.

Table 1

South Africa's rank in world trade (2008)

\begin{tabular}{|l|c|c|}
\hline \multicolumn{1}{|c|}{ Rank } & Exports & Imports \\
\hline Merchandise & 40 & 34 \\
Excluding intra-EU trade & 26 & 22 \\
Commercial services & 46 & 39 \\
Excluding intra-EU trade & 28 & 23 \\
\hline
\end{tabular}

Source: WTO (2009a)

Between 2003 and 2008, South Africa has been a net importer, consistently recording a trade balance deficit during this period. Specifically, South Africa is a net exporter to Africa and a net importer as far as trade with Europe, the Americas and Asia is concerned (Quantec, 2009). Developed countries and the emerging economies import natural resources from South Africa because South Africa has a significant endowment of natural resources and hence has a comparative advantage for these goods. On the other hand, emerging economies and the industrialised economies mainly export low-tech goods and high-tech manufactures to
South Africa respectively. South Africa's trading partners in the SADC region have a comparative advantage in natural resources as well and therefore the composition of trade between South Africa and its neighbours differs significantly from that between South Africa and developed countries (Smet, 2007:14). Large trade volumes both in terms of exports and imports are accounted for by the trade between South Africa and Asia, Europe and the Americas. South Africa imports more from Asia, Europe and the Americas than it exports to them (Quantec, 2009). The most important exports from and imports into South 
Africa are manufactured goods and minerals (DTI, 2009). This goes in line with the findings of Smet $(2007: 14-21)$ that South Africa is an exporter of mineral products and metals to the world. Imports into South Africa are mainly constituted by machinery, transport equipment and crude oil. The surge in the demand for transport equipment and machinery is mainly responsible for the negative trade balance in South Africa.

\subsection{Trade creation and trade diversion}

Trade creation refers to the net increase in trade resulting from a shift in high cost domestic goods to lower cost imported goods from a PTA member country. On the other hand, trade diversion refers to the shift of existing trade from lower cost non-PTA producers to a higher cost PTA member producer. Flynn (2008:1) argues that trade creation and trade diversion affect the economy differently. In general, trade creation, which results in a net economic gain, is the motive for countries to engage in PTAs given the fact that the price of an imported commodity is less than the domestic price of the same commodity. On the other hand, trade diversion generates a net economic loss whereby domestic consumers pay higher prices for imports from a high cost PTA member than they would have paid if the imports were sourced from a low cost non-PTA member.

The latest surge in the number of PTAs has revived the debate around the issue of the effects of trade creation and trade diversion and the relevancy of these agreements (Sarker \& Jayasinghe, 2007:102). According to Amposah (2002:2), the major issue with a preferential trade agreement is whether the gains from trade creation surpass the loss from trade diversion. Therefore a preferential trade agreement will be considered favourable if it produces greater trade creation than diversion. Trade creation and trade diversion form a major component of economic integration, i.e. the amalgamation of economic activities among countries. The intensity of trade creation and trade diversion diminishes as the countries' economies become highly integrated (Flynn, 2008:3).

Some authors such as Ghosh and Yamarik (2004), Musila (2005), Cernat (2003), Vicard
(2009) and Clausing (2001) suggest that generally, PTAs have net trade creation effects whereas Rahman, Shadat and Das (2006) and Coulibaly (2004) find evidence that some other PTAs (e.g. SADC, MERCOSUR) are associated with net trade diversion effects. Sarker and Jayasinghe (2007) find evidence that the EU has significantly increased agri-food trade among the members at the expense of trade with non-members, which reduced significantly. Using a cross-sectional estimation of the gravity model of bilateral trade based on 1998 data from a sample of 39 countries, Kwentua (2006) investigates the trade creation and trade diversion effects of the EU-SA agreement and finds evidence that both trade between members of the EU-SA agreement and trade between members and non-members of the EU-SA agreement increased, and therefore concludes that the EU-SA agreement is trade creating. Kwentua (2006) points out that the increase in trade between EU-SA members and the rest of the world could be attributed to an income effect. Based on 1994 to 2004 data covering 136 countries and using both cross-sectional and panel estimations, Holden and McMillan (2006) investigate whether the EU-SA and SADC agreements have had any effects on South Africa's trade. Their analysis also extends to the African Growth and Opportunity Act (AGOA) signed in 2000 between the USA and a host of African countries. The cross-sectional results find an insignificant impact while the panel results find evidence of a positive impact. Specifically, the panel results show that the EU-SA agreement stimulated both exports and imports during the period 1994 to 2004 whereas the SADC agreement only stimulated exports. The AGOA results were not significant, indicating that during that period, South African exports had not beneficiated from preferential access into the USA market.

\section{3}

Methodology

\subsection{The gravity model of bilateral trade}

In empirical research, the estimation of trade creation and trade diversion effects is mainly carried out in two ways: the use of Computable 
General Equilibrium (CGE) modelling or the use of the gravity model of bilateral trade. CGE modelling is relevant for ex-ante analysis, i.e. analysis done before trade between two countries actually takes place. The gravity model is appropriate for ex-post analysis, i.e. analysis done after trade has taken place between two countries (Cernat, 2003:7). Tinbergen and Pöyhönen first applied the gravity model to the study of international trade flows in the early 1960 s. Since then, a significant amount of research in international trade has used the gravity model of bilateral trade as their empirical tool because the model gives a better fit to the majority of regional as well as international trade flows data sets (Mátyás, 1998:397; Mátyás, 1997:363; Cheng \& Wall, 2005:49; Egger \& Pfaffermayr, 2003:571). Many authors, including Clausing (2001), Ghosh and Yamarik (2004), Cernat (2003), Musila (2005), Rahman, Shadat and Das (2006), Sarker and Jayasinghe (2007), Vicard (2009), Carrère (2006) and Coulibaly (2004) have used the gravity model of bilateral trade to assess trade creation and trade diversion using dummy variables that capture a country's membership in a preferential trade agreement.

The original form of the gravity model of bilateral trade assumes that trade flows between two countries can be likened to Newton's gravitational force between two objects. Trade flows are directly proportional to the countries' income (GDP) and inversely proportional to the distance separating them. A set of dummies can also be added in the specification of the model to account for factors enhancing or restraining the trade flow.

After the mid 1970s, there was a development in theories that supported the gravity model of bilateral trade. Anderson (1979) makes the initial formal endeavour to derive a gravity model of bilateral trade based on product differentiation. Anderson and Wincoop (2003) further argue that the major feature of the gravity model of bilateral trade is the dependence of trade flows on a trade resistance factor. In a quest to prove the strength of the theoretical foundation of the gravity model of bilateral trade, Oguledo and MacPhee (1994) derive a gravity model from a linear expenditure system.

The basic functional form of the gravity model of bilateral trade is as follows:

$$
X_{i j}=\frac{\kappa Y_{i}^{\alpha} Y_{j}^{\beta}}{D_{i j}^{\gamma}}
$$

where $X_{i j}$ represents bilateral trade flows (usually exports), $Y_{i}$ is the GDP (economic mass of country $i$ (reporter), $Y_{j}$ is the GDP of country $j$ (partner), $D_{i j}$ is the distance between countries $i$ and $j$.

The stochastic log-linearised version of the basic gravity model of bilateral trade is as follows:

$$
\log X_{i j}=\log \kappa+\alpha \log Y_{i}+\beta \log Y_{j}-\gamma \log D_{i j}+\varepsilon_{i j}
$$

where $\varepsilon_{i j}$ represents the white-noise error term.

According to Martinez-Zarzoso and NowakLehmann (2003:296), the generalised form of the gravity model of bilateral trade assumes that exports from country $i$ to country $j$ is a function of the countries' incomes, i.e. GDPs, their populations and the distance between them, as well as a vector of dummy variables:

$$
\begin{gathered}
X_{i j}=\phi_{0} Y_{i}^{\phi_{1}} Y_{j}^{\phi_{2}} N_{i}^{\phi_{3}} N_{j}^{\phi_{4}} D_{i j}^{\phi_{5}} A_{i j}^{\phi_{6}} u_{i j} \quad \begin{array}{l}
\text { estimation purposes, the generalise } \\
\text { model of bilateral trade is as follows: }
\end{array} \\
x_{i j}=\phi_{0}+\phi_{1} y_{i}+\phi_{2} y_{j}+\phi_{3} n_{i}+\phi_{4} n_{j}+\phi_{5} d_{i j}+\sum_{h} \phi_{h} A_{i j h}+u_{i j} \quad(h>5)
\end{gathered}
$$

where $X_{i j}$ represents bilateral trade flows (usually exports), $Y_{i}\left(Y_{j}\right)$ is the GDP of the exporting (importing) country, $N_{i}\left(N_{j}\right)$ is the population of the exporting (importing) country, $D_{i j}$ is the distance between capital cities or economic centres of the two countries, $A_{i j}$ captures any factor enhancing or restricting bilateral trade and $u_{i j}$ is the whitenoise error term.

Expressed in logarithmic form for estimation purposes, the generalised gravity 
where $\sum \phi_{h} A_{i j h}$ represents the sum of preferential trade dummy variables and $A_{i j h}$ takes the value of one when a given criterion is fulfilled (for instance being a member of a preferential trade agreement), zero otherwise. Lower-case letters represent the logarithm of respective variables, i.e. exports, GDPs, populations and distance.

\subsection{Model specification}

Variables: The specification of variables capturing trade creation and trade diversion effects in the gravity model of bilateral trade in this study follows the model specification in Ghosh and Yamarik (2004):

$$
X_{i j}=\phi_{0} Y_{i}^{\phi_{1}} Y_{j}^{\phi_{2}} N_{i}^{\phi_{3}} N_{j}^{\phi_{4}} E R_{i}^{\phi_{5}} D_{i j}^{\phi_{6}} P T A_{i j}^{\gamma_{1}} P T A_{i}^{\gamma_{2}} u_{i j}
$$

where $X_{i j}$ is the exports from South Africa to its trading partner, $Y_{i}$ is South Africa's GDP, $Y_{j}$ is the trading partner's GDP, $N_{i}$ is South Africa's population, $N_{j}$ is the trading partner's population, $E R_{i}{ }^{j}$ is the average real effective exchange rate of the rand, $D_{i j}$ is the distance between the capital cities of South Africa and the trading partner, $P T A_{i j}$ is a dummy variable capturing whether South
Africa and its trading partner both belong to the same preferential trade agreement (SADC or EU-SA), i.e. intra bloc trade, $P T A_{i}$ is a dummy variable capturing current membership status of South Africa in the preferential trade agreement.

The corresponding stochastic log-linear specification is:

$$
x_{i j}=\phi_{0}+\phi_{1} y_{i}+\phi_{2} y_{j}+\phi_{3} n_{i}+\phi_{4} n_{j}+\phi_{5} e r_{i}+\phi_{6} d_{i j}+\gamma_{1} P T A_{i j}+\gamma_{2} P T A_{i}+u_{i j}
$$

$P T A_{i j}=1$ if SA and its partner both belong to the same PTA, 0 otherwise $P T A_{i}=1$ if only SA is a member of the PTA, 0 otherwise

Contrary to the approach of defining PTAs whereby the value of PTA dummies is constant over time in a database and following Coulibaly (2004), the dummy variables $P T A_{i j}$ and $P T A_{i}$ in this study are time-variant. Therefore, these dummy variables will take the value of one only from the effective date of endorsement of the PTA. However, because these variables will have a constant value over time for some of the cross-sections, they will be estimated together with time-invariant variables as in Coulibaly (2004:4-5).

Expected signs: The relationship between exports and both GDP measures is expected to be positive. A higher GDP in South Africa means a higher production capacity which in turn translates into the ability of the South African economy to export more (supply side). On the other hand, a higher GDP for a trading partner country means a higher absorption capacity, i.e. the trading partner country is able to import more (demand side).

According to Martinez-Zarzoso and NowakLehmann (2003:296) and Armstrong (2007:5), there is no clear a priori relationship between exports and the populations of both the exporting and importing countries. The estimated coefficient of the exporter's population could either be positive or negative depending on whether the exporter has a large population and exports more (economies of scale) or the fact that the exporter has a large population but exports less (absorption effect). In the same vein, the estimated coefficient of the trading partner country's population could either be positive or negative.

Exports and the rand's exchange rate are expected to be positively related as higher rates of exchange (depreciation of the rand) would mean that it is cheaper for the trading partner country to source the required amount of rands to effect payments for imports, resulting in higher demand for South African exports.

Being a proxy for transportation costs, distance is normally expected to be negatively related to the flow of exports, i.e. the higher the distance, the higher the costs involved in trading and therefore a negative effect on trade flows. However, as shown by Marimoutou, Peguin and Peguin-Feissolle (2009) and Brun, Carrère, Guillaumont and de Melo (2005), distance can bear a different role in a gravity 
model of bilateral trade. Marimoutou et al. (2009) particularly show that the larger the trading partner country's GDP, the less the effect of distance on trade flows.

Trade creation and trade diversion effects in international trade studies are usually measured by using a pair of dummy variables $P T A_{i j}$ and $P T A_{i}$ (Ghosh \& Yamarik, 2004:215; Cernat, 2003:9). If $\gamma_{1}$ (the coefficient of $\left.P T A_{i j}\right)$ is positive, this is an indication that there is more intra PTA trade between South Africa and its trading partner than predicted by the other variables of the gravity model of bilateral trade. This is evidence of trade creation. On the other hand, if $\gamma_{2}$ (the coefficient of $P T A_{i}$ ) is positive, then extra PTA trade, i.e. trade between a PTA member and a non-PTA country is more than a random pair of countries. This indicates the openness of the PTA to imports from the rest of the world. Similarly, if $\gamma_{2}$ is negative, then there is less trade with non-PTA countries. This is evidence of trade diversion.

Alternatively, Cernat (2003:9) gives the following comprehensive interpretation of the signs of the PTA dummy variables' coefficients:

Trade creation \& trade expansion $=P T A_{i j}>0, P T A_{i}>0$

Trade diversion $=P T A_{i j}>0, P T A_{i}<0$

Trade expansion $=P T A_{i j}<0, P T A_{i}>0$

Trade contraction $=P T A_{i j}<0, P T A_{i}<0$

\section{4}

\section{Estimation}

According to Egger (2000:26) and Egger and Pfaffermayr (2003:571-572), many studies in the past have estimated the gravity model of bilateral trade using a cross-section methodology. However, as discussed in Egger (2000:26), Egger and Pfaffermayr (2003:571572) and Martinez-Zarzoso and NowakLehmann (2003:298), panel data estimation of the gravity model of bilateral trade has many advantages over cross-section analysis. For instance, the role of the business cycle and the interactions between variables over a long period of time can be captured by using panel data analysis. In addition, country-specific effects that do not change over time can be unravelled. Another benefit of using panel data analysis is that the risk of getting biased estimates is lowered.

The F-test is used to determine whether countries in the sample are homogeneous (poolability) or heterogeneous, i.e. the existence of country-specific individual effects. The test result rejects the null hypothesis of poolability in favour of the alternative hypothesis of country-specific individual effects by using fixed effects. ${ }^{3}$ As pointed out in Egger (2000:26), Martinez-
Zarzoso and Nowak-Lehmann (2003:298299), using a panel data framework results in the issue of choosing the correct specification of individual effects as either random or fixed effects. Mátyás (1997:365-366), Mátyás (1998:397-398), Egger (2000:26), Egger and Pfaffermayr (2003:572), Cheng and Wall (2005:54) and Martinez-Zarzoso and NowakLehmann (2003:299) opt for a fixed effects specification of the gravity model of bilateral trade. Egger (2000:26) and Martinez-Zarzoso and Nowak-Lehmann (2003:299) specifically argue that a fixed effects model is appropriate for studies that analyse trade flows between an ex-ante pre-selected group of countries. Since this study analyses the trade creation and trade diversion effects of the EU-SA and the SADC agreements with particular focus on trade between South Africa and its major trading partners over the period 1994 to 2008, the fixed effects specification of the gravity model of bilateral trade is used.

Following Martinez-Zarzoso and NowakLehmann (2003:298-299), time-invariant variables in the gravity model (such as distance) cannot be directly estimated with a fixed effects model as these variables would be eliminated in the estimation process. Such time-invariant variables can be estimated by running a separate regression with the time- 
invariant variables as the independent variables and the individual fixed effects as the dependent variables. The gravity model of bilateral trade in this study is therefore estimated in two stages as in Martinez-
Zarzoso and Nowak-Lehmann (2003:298299).

Stage one: Country-pair fixed effects model

$$
x_{i j}=\theta_{i j}+\phi_{1} y_{i}+\phi_{2} y_{j}+\phi_{3} n_{i}+\phi_{4} n_{j}+\phi_{5} e r_{i}+u_{i j}
$$

where $\theta_{i j}$ represents the individual fixed

Stage two: Pooled model effects.

$$
\theta_{i j}=\psi_{0}+\psi_{1} D_{i j}+\psi_{2} P T A_{i j}+\psi_{3} P T A_{i}+\mu_{i}
$$

where $\theta_{i j}$ represents the individual fixed effects, $D_{i j}$ is the distance between countries $i$ and $j, P T A_{i j}$ is a dummy variable capturing intra bloc trade, $P T A_{i}$ is a dummy variable capturing extra bloc trade and $\mu_{i}$ is the whitenoise error.

Data: The data set in this study comprises 585 observations which include 15 annual observations (1994-2008) for 39 countries representing South Africa's major trading partners. An exhaustive list of countries forming part of the sample is found in the Appendix. Table 4 (see Appendix) gives a description of variables used in this study as well as their sources. Panel unit root tests are conducted for each variable in the fixed effects model to ascertain that all variables are stationary before the actual estimation can be carried out. Results of panel unit root tests in Table 5 (see Appendix) report that all variables are stationary.

\section{5}

\section{Results}

Results for the first-stage estimation are reported in Table 2. Both GDP measures (for South Africa and the trading partner) are positive and statistically significant as per a priori expectation. South Africa's population has a significant negative effect on exports. Martinez-Zarzoso and Nowak-Lehmann (2003:296) and Armstrong (2007:5) argue that a negative relationship between exports and population is an indication of an absorption effect. This means that a country with a big population would indicate that the domestic market is large enough to 'absorb' a considerable share of domestically produced goods and thereby reducing the amount of domestically produced goods that could be exported. In this case, increases in the population size would result in lower exports. However, this argument would only seem to be relevant for countries where poverty is not a big issue. In the case of South Africa, a country with one of the highest Gini coefficients in the world, socio-economic factors such as crime and illiteracy could be an indirect cause of lower exports. For instance, higher population would relatively translate in a higher proportion of poverty. As a matter of fact, crime and poverty are closely related (Ludwig, Duncan \& Hirshfield, 2001). In turn, a higher incidence in the crime rate could negatively affect investment and productivity in an economy and thereby lower the export capacity. As per a priori expectation, Table 2 also shows that a weaker rand (higher exchange rate) enhances exports from South Africa to its trading partners.

Country-pair fixed effects are reported in Table 6 (see Appendix). These effects indicate the existence of specific factors that enhance or restrict trade between South Africa and a particular country. Countries with positive fixed effects (highlighted rows) such as the majority of SADC countries in the sample have individual specific factors (for instance geographic and cultural proximity in the case of SADC countries) that enhance their respective trade with South Africa. In the same vein, countries with negative fixed effects such as the USA, France and Nigeria have individual specific factors that constrain their respective trade with South Africa (for instance higher per capita income in the case of developed countries). 
Table 2

First-stage (fixed effects model) regression results

\begin{tabular}{|l|c|c|c|c|}
\hline \multicolumn{1}{|c|}{ Variable } & Coefficient & Std. Error & t-Statistic & Probability \\
\hline Constant term & -15.1766 & 19.58387 & -0.774954 & 0.4387 \\
Trading partner's GDP & 2.015886 & 0.341843 & 5.897113 & $0.0000^{* \star *}$ \\
South Africa's GDP & 3.597523 & 0.78496 & 4.583067 & $0.0000^{* * *}$ \\
Trading partner's population & 1.48654 & 0.61178 & 2.429862 & $0.0154^{* *}$ \\
South Africa's population & -7.80961 & 2.223251 & -3.512697 & $0.0005^{* * *}$ \\
Rand's average real exchange rate & 0.649182 & 0.212778 & 3.050981 & $0.0024^{* * *}$ \\
\hline \multicolumn{4}{|l|}{} \\
\hline Cross-section fixed (dummy variables) & Effects Specification \\
\hline R-squared & 0.851161 & Mean dependent var & 19.69459 \\
Adjusted R-squared & 0.839331 & S.D. dependent var & 1.819637 \\
S.E. of regression & 0.729375 & Akaike info criterion & 2.278976 \\
Sum squared resid & 287.8052 & Schwarz criterion & 2.607781 \\
Log likelihood & -622.601 & Hannan-Quinn criter. & 2.407118 \\
F-statistic & 71.94894 & Durbin-Watson stat & 0.619792 \\
Prob(F-statistic) & $0.0000^{* * *}$ & \\
\hline
\end{tabular}

*, **, ***: statistically significant at the $10 \%, 5 \%$ \& $1 \%$ levels respectively. All variables are in logs and estimations done in Eviews.

Table 3 presents the results of the second-stage estimation. In the case of South Africa, distance is reported to be playing its traditional role (proxy of trade costs) in a gravity model framework, i.e. distance has a small negative bearing on exports from South Africa to its trading partners. Most importantly, the signs of PTA dummies' coefficients are also reported in Table 3.

Table 3

Second-stage (pooled model) results

\begin{tabular}{|l|c|c|c|l|}
\hline \multicolumn{1}{|c|}{ Variable } & Coefficient & Std. Error & t-Statistic & Probability \\
\hline Distance & -0.00113 & $3.97 \mathrm{E}-05$ & -28.47009 & $0.0000^{\star * *}$ \\
Intra SADC & -0.753953 & 1.037383 & -0.726783 & 0.4677 \\
Extra SADC & -1.359736 & 0.503645 & -2.69979 & $0.0071^{* * *}$ \\
Intra EU-SA & 0.342076 & 0.624469 & 0.547787 & 0.5840 \\
Extra EU-SA & 1.386415 & 0.528904 & 2.621298 & $0.0090^{* * *}$ \\
Constant term & 8.209434 & 0.370337 & 22.16747 & $0.0000^{* * *}$ \\
\hline R-squared & 0.623635 & Mean dependent var & $-1.28 \mathrm{E}-10$ \\
Adjusted R-squared & 0.620385 & S.D. dependent var & 5.26685 \\
S.E. of regression & 3.24506 & Akaike info criterion & 5.202348 \\
Sum squared resid & 6097.108 & Schwarz criterion & 5.247185 \\
Log likelihood & -1515.687 & Hannan-Quinn criter. & 5.219822 \\
F-statistic & 191.8801 & Durbin-Watson stat & 0.022973 \\
Prob(F-statistic) & $0.0000^{\star * *}$ & \multicolumn{2}{|l}{} \\
\hline
\end{tabular}

*. **, ***: statistically significant at the 10\%,5\% \& 1\% levels respectively. Estimations done in E-views.

Following the interpretation à la Cernat (2003:9), there is significant evidence that the SADC preferential trade agreement has had a trade contraction effect. However, these results have to be taken with caution as the SADC preferential trade agreement had been scheduled to initiate a comprehensive implementation in 2008 only. In fact, countries 
like South Africa, Zimbabwe and Mauritius have liberalised their tariffs between 2000 and 2008 while on the other hand, Zambia, Malawi and Mozambique only effectively joined the trade agreement in 2008. Angola and the Democratic Republic of the Congo are set to join the trade agreement at a later stage. It is important to note that though the SADC as a development body has been in existence since 1996, the SADC preferential trade agreement started being implemented only in 2000. The SADC attained the status of a free trade area in January 2008 with imports tariffs on 85 per cent of all goods being eliminated in the initial 12 countries. There is also an indication that the SADC preferential trade agreement is yet in the process of facilitating trade (SADC, 2009). However, these results suggest that thus far, the agreement has not yet stimulated trade (both within and without the region) for the few countries that have been signatories prior to 2008. Therefore, a further encompassing and informative analysis of the SADC preferential trade agreement trade effects can only be carried out in the future. The EU-SA preferential trade agreement is reported to have both trade creation and trade expansion effects. However, due to the fact that the coefficient of intra EU-SA trade is not statistically significant and that only the coefficient of extra EU-SA trade is found to be statistically significant, this translates into the fact that countries in the EU-SA agreement are open and trade more with the rest of the world than a random pair of countries (Ghosh \& Yamarik, 2004:215). This goes in line with the empirical finding based on export data analysis that reveals a reduction of trade volumes between South Africa and some European countries and an increase in trade between South Africa and countries in the rest of the world such as China and Japan between 1994 and 2008.

\section{6}

\section{Conclusion}

This study investigated trade effects of the two most significant preferential trade agreements to which South Africa is a signatory (i.e. the SADC and EU-SA preferential trade agreements) following evidence of reduced trade between South Africa and some of its major trading partners in the EU-SA preferential trade agreement and increased trade between South Africa and countries in the rest of the world such as China and Japan.

Using a country-specific fixed effects panel data estimation of the gravity model of bilateral trade, the study reported that the SADC preferential trade agreement has had a trade contraction effect. However, this result is to be taken with prudence considering the fact that the SADC preferential trade agreement is not yet fully operational. On the other hand, the EU-SA preferential trade agreement has been reported to be trade expanding through increased trade between its signatories and the rest of the world.

Another important finding of this study was on the effect of the South African population on exports. The study reported that contrary to the absorption effect argument of MartinezZarzoso and Nowak-Lehmann (2003:296) and Armstrong (2007:5), socio-economic factors such as crime and illiteracy could be the catalysts of the negative relationship between exports and population size in South Africa. This argument of the socio-economic effect of population size on the productivity and export capacity of an economy extends to most developing countries as they are trapped in poverty.

Based on the fact that South Africa is an appealing trade partner due to its regional economic importance, and following Kowalski, Lattimore and Bottini (2009:8), trade policy in South Africa should focus on an extended multilateral liberalisation approach as supported by the findings of trade expansion effects of the EU-SA preferential trade agreement. The EU-SA did not significantly create more trade between its members; rather, there is evidence of more trade taking place between South Africa and non-EU members in the rest of the world. In this particular instance a preferential trade agreement should be considered as a second-best alternative as it conveys a risk of unnecessary discrimination. As far as the SADC preferential trade agreement is concerned, this initiative is profitable to other SADC countries (Kowalski, Lattimore and Bottini, 2009:48-49). Hence, in the objective of promoting regional economic stability and development, South Africa, as the 
regional economic hub, has an obligation to support the SADC preferential trade agreement initiative to stimulate trade and growth in the region. Nonetheless, also confirming the findings that it would be premature to assess the actual trade effects of the SADC preferential trade agreement, Kowalski,
Lattimore and Bottini (2009:48-49) point to the fact that the analysis of the importance of the SADC preferential trade agreement to South Africa is hampered because some trade flows among SADC countries are usually not reported.

\section{Acknowledgement}

Funding from Trade and Industrial Policy Strategies is hereby acknowledged

\section{Endnotes}

1 Currency misalignment refers in this case to the fact that a currency becomes overvalued as a result of the level of domestic consumer price exceeding the level of consumer price abroad when expressed in the same currency (Engel, 2009).

2 As a result of lower demand for South African exports due to higher prices, the levels of production declined, causing in turn a reduction in firms' profits and consequently job losses.

$3 F_{\text {crit }}(1.43)<F_{\text {Computed }}(54.99) \Rightarrow$ Reject $H_{0}$ (Homogeneity). Country-specific fixed effects are valid.

\section{References}

AMPONSAH, W.A. 2002. Analytical and empirical evidence of trade policy effects of regional integration: implications for Africa. [Online] Available at: http://www.uneca.org [Accessed 2009-5-8].

ANDERSON, J.E. 1979. A theoretical foundation for the gravity equation. American Economic Review, 69(1):106-116.

ANDERSON, J.E. \& VAN WINCOOP, E. 2003. Gravity with gravitas: a solution to the border puzzle. American Economic Review, 93(1):170-192.

ARMSTRONG, S. 2007. Measuring trade and trade potential: a survey. Asia Pacific Economic Papers, No. 368.

BRUN, J., CARRÈRE, C., GUILLAUMONT, P. \& DE MELO, J. 2005. Has distance died? Evidence from a panel gravity model. The World Bank Economic Review, 19(1):99-120.

CASSIM, R., ONYANGO, D. \& VAN SEVENTER, D.E. 2004. The state of trade policy in South Africa. Trade and Industrial Policy Strategies. [Online] Available at: http://www.tips.org.za (Accessed 2009-05-08]. CARRÈRE, C. 2006. Revisiting the effects of regional trade agreements on trade flows with proper specification of the gravity model. European Economic Review, 50(2006):223-247.

CERNAT, L. 2003. Assessing South-South regional integration: same issues, same metrics. Policy Issues in International Trade and Commodities Study Series, No. 21.

CHAUVIN, S. \& GAULIER, G. 2002. Regional trade integration in Southern Africa. Centre d'Etudes Prospectives et d'Informations Internationales (CEPII), working paper No. 2002-12.

CHENG, I. \& WALL, H.J. 2005. Controlling for heterogeneity in gravity models of trade and integration. Federal Reserve Bank of St. Louis Review, 87(1):49-63.

CLAUSING, K. A. 2001. Trade creation and trade diversion in the Canada-United States free trade agreement. Canadian Journal of Economics, 34(3):677-696.

COULIBALY, S. 2004. On the assessment of trade creation and trade diversion effects of developing RTAs. University of Lausanne. [Online] Available at: http://www.wif.ethz.ch [Accessed 2009-05-07].

EDWARDS, L. \& LAWRENCE, R. 2008. South African trade policy matters: trade performance and trade policy. Economics of Transition, 16(4):585-608.

EDWARDS, L. 2005. Has South Africa liberalised its trade? South African Journal of Economics, 73(4): 754-775.

EGGER, P. 2000. A note on the proper econometric specification of the gravity equation. Economics Letters, 66(2000):25-31.

EGGER, P. \& PFAFFERMAYR, M. 2003. The proper panel econometric specification of the gravity equation: a three-way model with bilateral interaction effects. Empirical Economics, 28:571-580. 
FLYNN, S.I. 2008. Trade creation and diversion. Ebsco research starters. [Online] Available at: http://web.ebscohost.com [Accessed 2009-04-19].

GHOSH, S. \& YAMARIK, S. 2004. Does trade creation measure up? A re-examination of the effects of regional trading arrangements. Economics letters, 82(2004):213-219.

HEAD, K. 2003. Gravity for beginners. University of British Columbia. [Online] Available at: http://economics.ca/keith/gravity.pdf [Accessed 2009-04-14].

HOLDEN, M. \& MCMILLAN, L. 2006. Do free trade agreements create trade for South Africa? Trade and Industrial Policy Strategies (TIPS). Trade and Industrial Monitor, No. 37.

JONSSON, G. \& SUBRAMANIAN, A. 2001. Dynamic gains from trade: evidence from South Africa. IMF Staff Papers, 48(1):197.

KALABA, M. 2007. Principles of trade: SA and its developed and developing partners. TradeInvestSA. [Online] Available at: http://www.tips.org.za [Accessed 2009-04-24].

KWENTUA, G.E. 2006. Trade creation and trade diversion effects in the EU-South Africa free trade agreement. Unpublished master's thesis. Louisiana State University. [Online] Available at: http://etd.lsu.edu [Accessed 2009-04-10].

KOWALSKI, P., LATTIMORE, R., \& BOTTINI, N. 2009. South Africa's trade and growth. OECD Trade Policy working papers, No. 91, OECD Publishing, OECD.

LUDWIG, J., DUNCAN, G. J. \& HIRSHFIELD, P. 2001. Urban poverty and juvenile crime: evidence from a randomized housing mobility experiment. The Quarterly Journal of Economics, 116(2):655-679.

MABUGU, R. \& CHITIGA, M. 2007. South Africa trade liberalization and poverty in a dynamic microsimulation CGE model. University of Pretoria, Department of Economics working paper, No. 2007-18. MAPCROW. 2009. Travel distance calculator and map between world cities, viewed 16 September 2009, http://www.mapcrow.info.

MARIMOUTOU, V., PEGUIN, D. \& PEGUIN-FESSOILLE, A. 2009. The 'distance-varying' gravity model in international economics: Is the distance an obstacle to trade? Economics Bulletin, 2(2):1157-1173.

MARTINEZ-ZARZOSO, I. \& NOWAK-LEHMANN, F. 2003. Augmented gravity model: an empirical application to MERCOSUR-European Union trade flows. Journal of Applied Economics, 6(2):291-316.

MATTHEE, M. \& NAUDÉ, W. 2007. Export diversity and regional growth: empirical evidence from South Africa. Working papers UNU-WIDER research paper, World Institute for Development Economic Research (UNU-WIDER).

MÁTYÁS, L. 1997. Proper econometric specification of the gravity model. The World Economy, 20(3): 363-368.

MÁTYÁS, L. 1998. The gravity model: some econometric considerations. The World Economy, 21(3): 397-401.

MTONGA, E. 2006. The real exchange rate of the rand and competitiveness of South Africa's trade. MPRA paper, No. 1192. [Online] Available at: http://mpra.ub.uni-muenchen.de [Accessed 2009-05-14].

MUSILA, J. W. 2005. The intensity of trade creation and trade diversion in COMESA, ECCAS, and ECOWAS: a comparative analysis. Journal of African Economies, 14(1):117-141.

OGULEDO, V.I., \& MACPHEE, C.R. 1994. Gravity models: a reformulation and an application to discriminatory trade arrangements. Applied Economics, 26(2):107.

PEET, M.A. \& KOCH, S.F. 2005. Technical barriers to trade faced by South African SMME'S. University of Pretoria, Department of Economics working paper. [Online] Available at: http://www.econrsa.org [Accessed 2009-07-25].

PETERSSON, L. 2005. Export diversification and intra-industry trade in South Africa. South African Journal of Economics, 73(4):785-802.

QUANTEC. 2009. RSA international trade database. [Online] Available at: http://www.quantec.co.za [Accessed 2009-04-04].

RAHMAN, M., SHADAT, W. \& DAS, N.C. 2006. Trade potential in SAFTA: an application of augmented gravity model. Centre for Policy Dialogue (CPD) occasional paper series, No. 61.

RANGASAMY, R. \& BLIGNAUT, B. 2005. How exposed is the South African economy to international trade? South African Journal of Economics, 73(3):366-388. 
RANGASAMY, L. \& BRICK, K. 2007. The implications of OECD growth for South African exports. South African Journal of Economics, 75(4):644-658.

SARKER, R., JAYASINGHE, S. 2007. Regional trade agreements and trade in agri-food products: evidence for the European Union from gravity modelling using disaggregated data. Agricultural Economics, (37): 93-104.

SMET, K. 2007. Stuck in the middle? The structure of trade between South Africa and its major trading partners. Vienna University of Economics \& B.A., working paper, No. 115.

SOUTH AFRICA. Department of trade and industry (DTI). 2009. Trade statistics. [Online] Available at: http://www.thedti.gov.za [Accessed 2009-04-22].

SOUTH AFRICAN RESERVE BANK. 2009. Online download facility. Available at: http://www.reservebank.co.za [Accessed 2009-09-24].

SOUTHERN AFRICAN DEVELOPMENT COMMUNITY (SADC). 2009. SADC free trade area. [Online] Available at: http://www.sadc.int/fta [Accessed 2009-05-15].

UNITED NATIONS STATISTICS DIVISION. 2009a. Commodity trade statistics database (COMTRADE). [Online] Available at: http://comtrade.un.org/db [24 September 2009].

UNITED NATIONS STATISTICS DIVISION. 2009b. Millennium Development Goals. [Online] Available at: http://mdgs.un.org/unsd/mdg [Accessed 2009-09-24].

VICARD, V. 2009. On trade creation and regional trade agreements: Does depth matter? Review of World Economics, 145(2):167-187.

WORLD TRADE ORGANISATION. 2009a. Trade profiles 2009: SA rank in international trade (2008). [Online] Available at: http://www.wto.org [Accessed 2010-01-04].

WORLD TRADE ORGANISATION. 2009b. Regional trade agreements gateway. [Online] Available at: http://www.wto.org [Accessed 2009-07-18].

WORLD TRADE ORGANISATION. 2009c. Regional trade agreements by WTO member. [Online] Available at: http://www.wto.org [Accessed 2009-07-18].

\section{Appendix}

\section{List of countries [2009 exports rank as in DTI (2009)]}

China - (CHINAS)

United States - (NAFTA)

Japan - (North-East Asia)

Germany - (EU)

United Kingdom - (EU)

Switzerland - (EFTA \& OTHER)

Netherlands - (EU)

India - (SAARC)

Mozambique - (SADC)

Zimbabwe - (SADC)

Zambia - (SADC)

Belgium - (EU)

Spain - (EU)

Italy - (EU)

Hong Kong - (CHINAS)

Kenya - (North-East Africa)

Korea Rep. South - (North-East Asia)

Angola - (SADC)

France - (EU)

Australia - (Pacific-Continent)
Nigeria - (West Africa)

United Arab Emirates - (Middle East)

Dem. Rep. of Congo - (SADC)

Israel - (Middle East)

Malaysia - (ASEAN)

Tanzania - (SADC)

Canada - (NAFTA)

Malawi - (SADC)

Poland - (Central Europe)

Singapore - (ASEAN)

Ghana - (West Africa)

Indonesia - (ASEAN)

Brazil - (MERCOSUR)

Mauritius - (SADC)

Saudi Arabia - (Middle East)

Thailand - (ASEAN)

Afghanistan - (South Middle Asia)

Turkey - (Middle East)

Sweden - (EU) 


\section{Table 4}

Data Sources

\begin{tabular}{|c|l|c|}
\hline \begin{tabular}{c|c} 
Variable \\
$X_{i j}$
\end{tabular} & \multicolumn{1}{|c|}{ Definition } & Source \\
$Y_{i}$ & GDP of country $i$ (constant 1990 USD prices) & UN Statistics (2009a) \\
$Y_{j}$ & GDP of country $j$ (constant 1990 USD prices) & UN Statistics (2009b) \\
$N_{i}$ & Population of country $i$ & UN Statistics (2009b) \\
$N_{j}$ & Population of country $j$ & UN Statistics (2009b) \\
$E R_{i}$ & Real effective exchange rate of country $i$ 's currency: Average & SA Reserve Bank \\
$D_{i j}$ & Distance between capital cities of country $i$ and country $j$ & Mapcrow \\
$P A_{i j}$ & PTA dummy (intra PTA) & WTO (2009c) \\
$P T A_{i}$ & PTA dummy (extra PTA) & WTO (2009c) \\
\hline
\end{tabular}

\section{Table 5}

Panel unit root tests

\begin{tabular}{|c|c|c|c|c|}
\hline & (LLC) & (IPS) & ADF - Fisher & PP - Fisher \\
\hline Export & $-7.278(0.000)^{\star \star *}$ & $-5.768(0.000)^{\star \star *}$ & $199.714(0.000)^{\star * *}$ & $252.749(0.000)^{* \star *}$ \\
\hline South Africa's GDP & $-16.256(0.000)^{\star * *}$ & $-11.010(0.000)^{* * *}$ & $250.916(0.000)^{* * *}$ & $243.852(0.000)^{* * *}$ \\
\hline Trading partner's GDP & $-3.050(0.001)^{* * *}$ & $-4.360(0.000)^{* * *}$ & $153.139(0.000)^{\star * *}$ & $149.592(0.000)^{* * *}$ \\
\hline South Africa's population & $-19.257(0.000)^{\star * *}$ & $-13.661(0.000)^{\star * *}$ & $321.886(0.000)^{* * *}$ & $109.527(0.011)^{\star \star}$ \\
\hline Trading partner's population & $-3.504(0.000)^{* * *}$ & $-6.679(0.000)^{* * *}$ & $193.937(0.000)^{* * *}$ & $103.864(0.027)^{\star \star}$ \\
\hline
\end{tabular}

*, **, ***: statistically significant at the $10 \%, 5 \%$ \& $1 \%$ levels respectively.

Probabilities are given in brackets

\section{Table 6}

Country-specific fixed effects

\begin{tabular}{|l|c|}
\hline \multicolumn{1}{|c|}{ Country } & $\theta_{i j}$ \\
\hline China & -9.60513 \\
USA & -9.45996 \\
Japan & -6.79264 \\
Germany & -5.27949 \\
UK & -3.60999 \\
\hline Switzerland & 1.306397 \\
\hline Netherlands & -0.01945 \\
India & -8.26127 \\
\hline Mozambique & 7.526639 \\
Zimbabwe & 7.783062 \\
Zambia & 8.885511 \\
Belgium & 3.613247 \\
\hline Spain & -3.18211 \\
\hline
\end{tabular}




\begin{tabular}{|l|c|}
\hline Italy & -4.79597 \\
\hline Hong Kong & 2.543414 \\
Kenya & 4.196852 \\
\hline Korea, Rep. & -2.8676 \\
\hline Angola & 5.391001 \\
\hline France & -5.43404 \\
\hline Australia & -1.42071 \\
\hline Nigeria & -1.46285 \\
\hline United Arab Emirates & 4.331441 \\
\hline Congo, Dem. Rep. & 4.804475 \\
\hline Israel & 3.174895 \\
\hline Malaysia & 0.325007 \\
\hline Tanzania & 4.62068 \\
\hline Canada & -4.03427 \\
\hline Malawi & 8.358386 \\
\hline Poland & -1.68018 \\
\hline Singapore & 3.624856 \\
\hline Ghana & 4.594973 \\
\hline Indonesia & -4.76837 \\
\hline Brazil & -6.15357 \\
\hline Mauritius & 11.22755 \\
\hline Saudi Arabia & -0.74891 \\
\hline Thailand & -1.93455 \\
\hline Afghanistan & 0.263473 \\
\hline Turkey & -1.83372 \\
\hline Sweden & \\
\hline & -22708 \\
\hline
\end{tabular}

